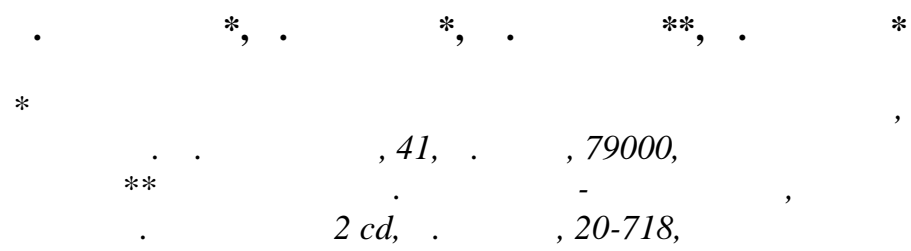

озріз орг новичі розт шов ний у ередк рп тті, з хідніше м. мбір, ьвівської обл. ін репрезентує люві льну і покривну товщі рівня оєвої - шостої н дз пл вної тер си ністр . східній околиці сел розміщений розріз орг новичі 1, н 3 хідній - орг новичі $2 . \quad$ ведено описи розрізів, деякі результ ти н літичних досліджень відкл дів, окреслено в жливість вивчення розрізів для геоморфології і п леогеогр фії ередк рп ття. тер си.

лючові слов : опорний розріз, рівень оєвої, гляці льний і флюві льний літо- і морфогенез,

озрізи орг новичі 1, 2 є, н н ше глибоке перекон ння, дуже в жливими з погляду з'ясув ння декількох фунд мент льних проблем четвертинної геології і геоморфології ередк рп ття з г лом і долини ністр зокрем . ивчення розрізів н близять н с до вирішення проблеми ч су н копичення лювію рівня оєвої (шостої тер си ністp ), межі зледеніння, перебігу процесів плейстоценового флюві льного, гляці льного т суб ер льного морфо- і літогенезу т деяких інших.

івень оєвої, як виплив є з результ тів н ших н йновіших досліджень, н межиріччі ністр - тривігору скомпонов ний з декількох гіпсометрично близьких між собою рівнів. рин ймні, н підст ві н лізу морфометричних критеріїв вд лося виокремити чотири т кі рівні. евеликі переп ди висот між східцеподібними цоколями, різновисотними горизонт ми гр війно-г лечникового м тері лу виявлених рівнів з м сков ні зверху лесовим покривом, тому в рівні оєвої вони пр ктично не вир жені [2].

озрізи орг новичі 1, 2 репрезентують будову, ймовірно, гіпсометрично н йвищого блок рівня оєвої (шостої тер си), що розвинений н 3 ході межиріччя тривігоруністр (р йон сіл орчиновичі- орг новичі- влівк ). ут він формує вузький вододіл ністр - тривігору (р. сениці) і сениці- линівки. 3 ході, поблизу рп т, денн поверхня тер си досяг є 360-370 м, м ксимум - 381 м, що ст новить 60-70 м н д руслом тривігору і 50-60 м н д руслом ністр . околь тер си піднім ється, відповідно, н 45-50 м н д руслом тривігору і н 35-40 м н д руслом ністр т перекритий зверху люві льним гр війно-г лечниковим м тері лом винятково к рп тського походження.

зн чимо, що ближче до рп т зберігся л нцюг гіпсометрично близьких, ізольов них між собою т відмежов них від рп т вершин, бсолютні висоти яких близькі до 400 м. ершини сконцентров ні між рівнем оєвої (у її суч сних меж х [1]) т пів-

огуцький ., митрук ., нчонт ., цишин ., 2010 
нічно-східним м кросхилом рп т і простяг ються від орг новичів через н селені пункти т р іль, умин, ерезів до оляни. околицях сел орг новичі до цього л нцюг ми з числяємо дві вершини з бсолютними позн чк ми 400,0 і 406,7 м.

кл д ється вр ження, що це колись суцільн, тепер розчленов н невеликими поток ми і яр ми поверхня, відносні висоти якої стосовно русл тривігору досяг ють 80-90 м, ністр - 70-80 м. д ними гіпсометрії, поверхня дуже близьк до рівня р сної, від якої вон гіпсометрично нижч м ксимум н 10 м. одо рівня оєвої, вон , н вП ки, гіпсометрично вищ н 20-30 м.

искусійним є пит ння іï вікової позиції - чи це фр гменти колись монолітних поверхні р сної бо поверхні оєвої, розбитих под льшими тектонічними рух ми н окремі блоки, бо ж це окрем (?), молодш від р сної, ле д вніш від оєвої, поверхня.

озрізи орг новичі 1, 2 розт шов ні н привододільній ч стині межиріччя ністр тривігору (межиріччя ністр - сениці) н відст ні близько 4 км від місця виходу ністр 3 рп т. бсолютні відмітки н вододілі досяг ють 365-375 м, подекуди зрост ють до 381 м, що ст новить 50-60 м н д руслом ністр і 60-70 м н д руслом тривігору. околь тер си піднім ється н 35-40 м н д руслом ністр т н д руслом тривігору.

, отже, підст ви стверджув ти, що вивчення розрізу орг новичі н близить н с до тр ктув ння рівня (рівнів - ?) оєвої. и схильні дум ти, що з лишиться менше проблем і у вирішенні пит нь льодовикового комплексу ередк рп ття, включ ючи проблему впливу зледеніння н формув ння річкових долин.

розуміло, що у вивченні розрізу орг новичі ще необхідно дуже б г то зробити. ижче н ведено опис розрізу й деякі результ ти його н літичного вивчення.

озріз орг новичі 1, з чистк 1. озт шов н н східній околиці сел в глибокій дорожній виїмці-дорозі, що веде від сел н поля, вододіл. ж ль, не вд лось розчистити верхню ч стину розрізу (дуже з дернов но, потужний нтропогенний покрив тощо), тому опис розпочин ємо з середньої ч стини схилу, н д глинищем. о брівки схилу - 4,0 м (див. рисунок).

нтропогенні відкл ди, перев жного коричневого кольору, супіщ ні, переповнені корінням рослин. ерехід ясний.

упіски голубув то-сірі (7,5 YR 8/1), ш рув ті, що виділене чорними i бурими з лізисто-м нг новими конкреціями до 3,0 мм ді метром, т кож смуг ми бурого оз лізнення потужністю до 2 см. р пляються т кож тонкі (перші міліметри) прош рки т лінзочки глинистого жовтув то-бурого піску. ш рі інтенсивне оглеєння, що н д є йому голубув того відтінку; із соляною кислотою не вз ємодіють. ороди т кож оз лізнені й ом нг нов ні. видше з все, це підгоризонт соліфлюкції н д луцьким грунтом. ижній конт кт ясний, хвилястий, очевидно, ерозійний.

упіски однорідні, світло-коричневого (7,5 YR 7/6) кольору, безк рбон тні, щільні, з великою кількістю чорних і бурих з лізисто-м нг нових новоутворень до 3,0 мм ді метром. ороди несуть сліди незн чного оглеєння й оз лізнення, що виявляється у кольорі. ожлливо, що це нижня ч стин горизонту луцького грунтового комплексу. ерехід поступовий, з зміною кольору.

$0-0,7$ м

$0,7-1,5 \mathrm{M}$

$1,5-1,8 \mathrm{M}$ 

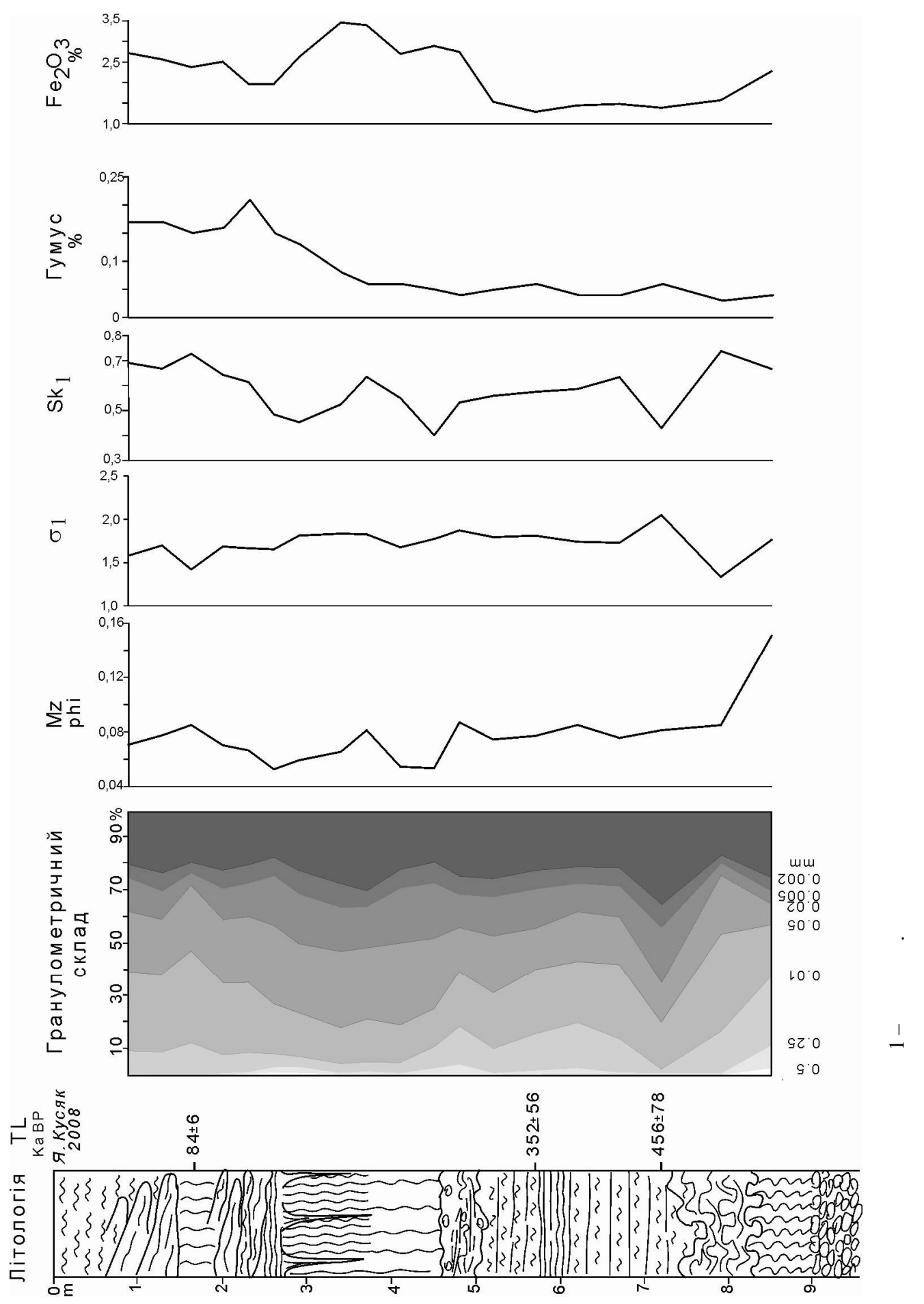
дсок льськ соліфлюкційн п чк . кл ден супіск ми, безк рбон тними, голубув то-сірими (7,5YR8/1), неяснош рув тими, що виділене плівк ми бурого оз лізнення. рув тість хвиляст, більше прит м нн нижній половині ш ру. ш рі б г то з лізисто-м нг нових конкрецій до 4,0 мм ді метром. ерехід поступовий.

днорідніші й менш оглеєні супіски, м кропористі, темно-п левого кольору, які генетично пов'яз ні з соліфлюкційною п чкою i, очевидно, $€$ його нижньою ч стиною. 3-3 нерівного нижнього конт кту м є змінну потужність, іноді вон менше $10 \mathrm{~cm}$. ш рі т кож б г то здебільшого чорних з лізисто-м нг нових конкрецій ді метром до 2 мм, іноді більше.

ок льський викопний грунт. $є$ прекр сно розвинений горизонт і горизонт .

оризонт потужністю до 0,3 м м є білястий (відтінок к к о) (10 YR 8/1) колір, однорідний, безк рбон тний, легкосупіщ ний (пудр ), переповнений чорними з лізисто-м нг новими конкреціями ді метром до 5 мм. ижній конт кт ясний, з зміною кольору, щільності, місцями язикув тий. зики-тріщини шириною до декількох с нтиметрів і глибиною до 0,5 м з повнені білястою “пудрою”. і тріщини проник ють у горизонт через кожні 0,3-0,4 м. ноді вони сл бко н хилені по д вньому рельєфу.

оризонт потужністю 1,1 м з профілем неоднорідний:

верхня ч стин ' червонув то-бурого кольору (10 YR 6/6), безк рбон тн, дуже оглеєн й оз лізнен, переповнен тріщин ми з м тері лом горизонту і сизим глеєм, т кож великою кількістю (особливо у верхній половині) з лізисто-м нг нових конкрецій до 5 мм ді метром.

окремих ділянк х м є чітку комірч сту текстуру з розміром комірок до $1 \mathrm{~cm}$. р неоднорідний. ерехід з зрост нням однорідності порід, з г лом поступовий;

супіщ ний, його потужність - 0,4 м. упіски однорідні, оглеєні, світлокоричневі (10 YR 8/4), безк рбон тні, з меншою кількістю з лізистом нг нових конкрецій ді метром до 3 мм.

ижній конт кт ясний, з зміною кольору, появою ш рув тості.

пис зміщуемо трохи вниз по цій же стінці, до пр вого боку (з чистк 2). ітко ш рув т п чк лесового обрису темно-п левого (10 YR 2) кольору. редст влен супіск ми з прош рк ми глинистих пісків потужністю до 1 см. чк оглеєн , безк рбон тн , з великою кількістю з лізисто-м нг нових конкрецій, дуже нерівним нижнім конт ктом, що виділене плівк ми бурого оз лізнення. мінюється т кож гр нулометричний скл д.

рув т п чк 3 г льного бурого кольору (10 YR 7/6), дуже неоднорідн , скл дно плік тивно деформов н , оглеєн, н повнен чорними 3 лізисто-м нг новими конкреціями ді метром до 5,0 мм, з піщ ними лінз ми і прош рк ми, що м ють головно ор нжево-бурий (7,5 YR 6/8) колір. в окремих прош рк х і лінз х тр пляються сизі (5 YR 8/1) супіски, які з ляг ють у розрізі нижче. йх р ктернішою ж озн кою п чки є вміст великих ул мків перев жно ск ндин вського походження 
(ер тики) і пісковиків до 20 см ді метром. ижній конт кт нерівний, хвилястий.

чк сизого кольору (5 YR 8/1), супіш н, ш рув т, ш рув тість виділен бурим оз лізненням, яке по ш ру неоднорідне. глибині близько 1 м від поверхні ш ру виділений прош рок потужністю до 0,8 м, де оз лізнення і ш рув тість особливо інтенсивні. писув н п чК, очевидно, озерно-льодовиков , уся кріогенно деформов н . еформ ції головно тріщинні, з відгин нням порід по конт кт х доверху. ріщини вузькі (перші с нтиметри), з повнені здебільшого піск ми. о всьому ш ру є чорні з лізисто-м нг нові конкреції до кількох міліметрів ді метром. приповерхневій ч стині ш ру тр пляються включення ер тичного м тері лу ді метром до $15 \mathrm{~cm}$.

розрізі орг новичі (з чистк 3, що нижче по схилу) описуємо п чку, що з ляг є безпосередньо н д русловим лювієм, тобто під опис ною т опробув ною озерною. ідошв озерної п чки дуже нерівн , тому в жко визн чити її спр вжню потужність. ожливо, що потужність цієї п чки - 3,0 м і н віть більше.

третьому профілі орг новичів є дв ш ри. ерхня - потужністю до 0,8 м, тобто в інтерв лі 7,5-8,3 м.

оловно піски, з прош рк ми супісків, які домінують біля верхнього конт кту. ерев жний колір порід бурий (7,5 YR 8/4). ся п чк плік тивно і структурно деформов н . ітко виділені скл дки висотою до 0,9 м і шириною до 1,0 м. нтиклін льних скл дк х (поблизу ш рнірів) спостеріг ють н йгрубші піски. ноді тут розпочин ються клиноподібні піщ ні структури, дещо похилені по п леорельєфу. ожливо, що це мерзлотні деформ ції типу плям-мед льйонів.

ижній ш р профілю 3 скл дений дуже неоднорідними глинистими піск ми червонув то-бурого (5 YR 6/6) кольору, оглеєними, оз лізненими. постеріг ють включення г льки пісковиків до 2,0 см ді метром. ноді простежують м лопотужні (перші с нтиметри) плік тивно деформов ні прош рки т лінзи сизих супісків. ш рі 6 г то чорних 3 лізисто-м нг нових конкрецій ді метром до декількох міліметрів. пород х іноді видно прекр сну комірч сту текстуру з ді метром комірок до 1,5 см. ш рі тр пляються гнізд яскр во-жовтого (10 YR 8/6) дрібнозернистого піску. $\quad$ н ше перекон ння, це горизонт одного із грунтів комплексу з гвіздя (нижннього ?). енетично опис н п чк може бути з пл вним лювієм шостої н дз пл вної тер си.

чистк 4 розт шов н 3 пр вого боку цієї ж дорожньої виїмки, м йже н впроти 3 чистки профілю 3 . чищено 1,5 м, тобто до глибини 10,5 м. е крупноул мковий русловий лювій червонув то-бурого кольору (7,5 YR 5/8), дуже щільний, оз лізнений (місцями н віть сл бкозцементов ний), з невеликою кількістю піщ но-глинистого н повнюв ч . л мки різної форми й обк т ності, причому досить високий вміст плоских г льок. льк і в луни скл дені головно пісковик ми різної щільності й кольору, 3 м ксим льними розмір ми до 20 см у поперечнику. ерев жно розмір ул мків не перевищує 10 см. крім пісковиків, у скл ді г льки тр пляються силіцити. рист лічного м тері лу не виявлено. лювій з ляг є н корінних відкл д х. 
озріз орг новичі 2. озт шов ний у з хідній ч стині сел, н привододільному схилі, у придорожній виїмці дороги, що йде від головної дороги сел н поля. е шост тер с ністр . озріз розкритий ч стково розчисткою, ч стково свердловиною ручного буріння. о г лечнику, що є по цій же дорозі нижче, ближче до сел , добуритись ми не змогли, до нього, можливо, ще кільк метрів.

уч сний грунт, сформов ний, очевидно, н д внішому грунті бо грунтовому комплексі (горохівському?, коршівському?). розрізі неоднорідний.

нтропогенно змінен ч стин (0,3 м) гумусного горизонту ( ). оризонт суглинистий, безк рбон тний, пухкий, світло-коричневий (7,5 YR 6/6), переповнений корінням рослин. ерехід поступовий.

осить однорідн п чк (інтерв л 0,3-2,5 м, тобто потужність 2,2 м), скл ден легкими суглинк ми дуже своєрідного обрису: вони червонув то-коричневі (основний фон 7,5 YR 6/8), дуже оглеєні, колір дуже сизий $(7,5$ YR 7/1). лей $з$ повнює м йже вертик льні тріщини шириною до 2,5 см т утворює горизонт льні прош рки, що виділяє ш рув тий обрис п чки. ут б г то темно-бурих 3 лізисто-м нг нових новоутворень, здебільшого пухких, ді метром до 3 мм. ноді ці новоутворення формують горизонт льні смуги, що т кож виділяє ш рув тість п чки.

нижніх 0,5 м п чки суглинки м йже сизі, тут 6 г то з лізисто-м нг нових прим зок, зрост є однорідність порід. ижній конт кт ясний.

углинки дуже щільні, м кропористі, досить однорідні, оглеєні (виділяються кільк горизонт льних оглеєних смуг, що тяжіють до покрівлі ш ру і м ють потужності не більше декількох с нтиметрів). олір суглинків зеленкув то-жовтий (10 YR 7/8). ш рі 6 г то бурих і чорних, зрідк вишневих, з лізисто-м нг нових прим зок і новоутворень типу кілець ізег нг . ижній конт кт фіксов ний смугою ірж вобурого оз лізнення потужністю до 2,0 см, н д нею ще кільк с нтиметрів смуг бурого оз лізнення. ідтінок бурого кольору світліший.

осить однорідний жовтув то-сірий (7,5 YR 7/4) лес, м кропористий, легкосуглинистий (н гр ні супісків), безк рбон тний, з поодинокими чорними з лізисто-м нг новими конкреціями ді метром до 3 мм. окремі плями оз лізнення. глеєння порід незн чне.

ижній конт кт проводимо умовно, оскільки літологічно породи змінені м ло, проте змінен їхня структур і збільшене ом нг нув ння п чки.

углинки легкі (до супісків), літологічно близькі до опис них вище порід. они безк рбон тні, у верхніх 0,15 м дуже $3 б$ г чені чорними (очевидно, м нг новими) лінз ми (висотою до 0,1 м і шириною до 0,2-0,25 м). орне ом нг нув ння виділяе неповносітч сту посткріогенну текстуру п чки (висот сітки $0,3-0,6$ см), особливо добре розвинену в припокрівлевій ч стині ш ру. ля ш ру х р ктерні чорні з лізисто-м нг нові новоутворення ді метром до 3 мм. ерев жний колір суглинків світло-коричневий (10 YR 6/4). ерехід ясний, 3 появою чіткої ш рув тості. 
іткош рув т п чк 3 домінув нням прош рків перев жно голубув тосірого (7,5 YR 8/1) кольору, є т кож прош рки п левого (7,5 YR 7/6) кольору. отужність прош рків - до 5-6 см. кл д порід супіщ ний. упіски безк рбон тні, з великою кількістю з лізисто-м нг нових чорних новоутворень ді метром до 3 мм, є т кож смуги бурого оз лізнення. простяг нням ця п чк мінлив , іноді це однорідний лес. ижній конт кТ ясний.

ес п левий (10 YR 7/4), безк рбон тний, супіщ ний, однорідний. ижній конт кт ясний, у ш рі велик кількість чорних і бурих з лізисто-м нг нових новоутворень до 5 мм ді метром.

чевидно, н длуцьк соліфлюкційн п чк . он супіщ н, ш рув т, голубув то-сір (2,5 Y 8/1). істить велику кількість чорних і бурих 3 лізисто-м нг нових новоутворень ді метром до 5 мм. ороди безк рбон тні, щільні, з різким нижнім конт ктом, що виділений оз лізненням.

оризонт луцького викопного грунту. верхніх 0,2 м супіски щільні, червонув то-коричневого кольору (7,5 YR 7/8), досить однорідні, зі зн чною кількістю чорних і бурих з лізисто-м нг нових новоутворень ді метром до 2 мм. ижні 0,4 м ш ру скл дені супіск ми більш оглеєними, через що н був ють голубув того (7,5 YR 7/3) відтінку. ут ще більше зрост ють щільність, вологість, оз лізнення й кількість 3 лізисто-м нг нових новоутворень до 5 мм ді метром. ижній конт кт різкий, нерівний, очевидно, ерозійний.

ерхня ч стин цього ш ру (верхні 0,1 м) - це суцільний ш рув тий глей голубув то-сірого кольору (10 YR 8/2). ижня ч стин (нижні 0,3 м) ш ру однорідніш , з г льного лесового обрису, супіш н , світлокоричневого кольору (10 YR 7/6). ороди щільні, безк рбон тні, зі зн чною кількістю чорних і бурих з лізисто-м нг нових конкрецій діметром до 3 мм. ижній конт кт ясний, очевидно, ерозійний. ше 3 все, цей ш р можн розгляд ти як лес між луцьким т сок льським грунт ми.

цьому інтерв лі сок льський викопний грунт з прекр сно розвиненими горизонт ми елюві льним ( ) т ілюві льним ( ).

оризонт м є потужність до 0,5 м. ін білястий (5 Y 8/1), переповнений чорними з лізисто-м нг новими щільними конкреціями ді метром до 1 см. оризонт супіщ ний (“пудр ”), оз лізнений, неяснош рув тий. ерстви іноді хвилясті, що свідчить про їхню плік тивну (соліфлюкційну ?) деформов ність. ороди безк рбон тні. ижній конт кт ясний, з зміною кольору і щільності. лейові тріщини шириною до 2,0 см проник ють з горизонту в горизонт н глибину до 0,7 м. они дещо деформов ні й м ють н хил по д вньому рельєфу. оризонт сок льського грунту неоднорідний. оризонт ' м є потужність 0,7 м і скл дений суглинк ми червонув токоричневого кольору (7,5 YR 6/8), суглинистий, оз лізнений, оглеєний, з великою кількістю з лізисто-м нг нових новоутворень, перев жно чорних, ді метром до 5 мм.
$4,55-4,8 \mathrm{~m}$

$5,2-5,8 \mathrm{M}$

$5,8-6,4$ м

$6,4-6,8$ м

$6,8-8,0 \mathrm{M}$ (до дН 3 чистки) 
p ктерною рисою ш ру є велик кількість тріщин із сизим глейовим н повнюв чем, дещо н хилених у н прямі д внього схилу.

нижніх 0,2 м ілюві льного горизонту (поч ток ") дещо зменшен кількість глею, у кольорі менше червоного відтінку (10 YR 7/8). ороди дещо меншої щільності. меншен т кож кількість з лізистом нг нових конкрецій.

глибини 8,0 м з чистк поглиблен свердловиною ручного буріння.

родовження горизонту " сок льського грунту. тері л суглинистий, безк рбон тний, дуже оглеєний, щільний, ірж во-бурого кольоpy, н ділянк х оглеєння колір голубув то-сірий (відповідно, 7,5 YR 7/6 i 7,5 YR 7/1).

оризонт сок льського грунту. упіски, місцями суглинки, жовтув тоcipi (7,5 YR 6/1), оглеєні.

ес суглинистий (суглинки в жкі), безк рбон тний, щільний, жовтув тосірий (7,5 YR 8/4). ерехід з зміною літології.

глибині 10,0 м тр пилось зерно польового шп ту до 1,0 cм у поперечнику.

іски жовті (7,5 YR 8/6), глинисті, безк рбон тні, досить однорідні. ерехід ясний, з зміною літології.

углинки жовтув то-сірі (7,5 YR 7/4), в жкі, безк рбон тні, оглеєні, оз лізнені, н окремих ділянк х ш рув ті.

есь інтерв л скл дений темно-п левими (7,5 YR 6/6) суглинк ми, безк рбон тними, щільними. нижніх 0,7 м інтерв лу гр нулометричний скл д дещо полегшений. углинки вологі. них де-не-де тр пляються ул мки польових шп тів (глибин - 11,4 м, 12,3 м до 1,5 см $8,0-8,7 \mathrm{M}$ у поперечнику).

о г лечників, які з ляг ють н цьому ж схилі дещо ближче до сел, добуритись ми не змогли. е, без сумніву, г лечники шостої тер си ністр (рівня оєвої). Зг д ному відслоненні їхня розкрит потужність досяг є м ксим льно 4 м. они н логічні до г лечників орг новичі 1 і скл дені винятково к рп тським м тері лом. лечники з ляг ють н корінних відкл д х.

1. емедюк . . оверхности выр внив ния кр инских рп т и их предгорий // Studia Geomorphologica Carpatho-Balkanica. 1983. Vol. 16. S. 3-14.

2. цишин ., огуцький ., лотніков . т пи формув ння т геоморфологічн будов долини

p. тривігор у меж х ередк рп ття // існ. ьвів. ун-ту. ер. геогр. 2008. ип. 35. .348-360. 


\title{
TORHANOVYCHI - A NEW PLEISTOCENE KEY PROFILE IN THE FORE-CARPATHIANS
}

\author{
A. Bogucki*, R. Dmytruk*, M. Lanchont**, A. Jacyshyn* \\ *Ivan Franko National University of Lviv, \\ . Doroshenko St., 41, UA - 79000 Lviv, Ukraine \\ **Maria Curie-Sklodowska University, \\ Kraśnitcka St., 2 cd, PL-20718 Lublin, Poland
}

Torhanovychi profile is located in the Fore-Carpathians, to the west of Sambir in Lviv region. It represents alluvial and sub-aerial strata of Loyeva level - the sixth terrace of the Dnister. The profile Torhanovychi 1 is located at the eastern part of the village, while the profile Torhanovychi 2 is located in the western part. The descriptions of the profiles are given as well as some results of laboratory testings. The importance of the profiles study for the geomorphology and palaeogeography of the ForeCarpathians is discussed.

Key words: key profile, Loyeva level, glacial and fluvial lito- and morphogenesis, terraces.

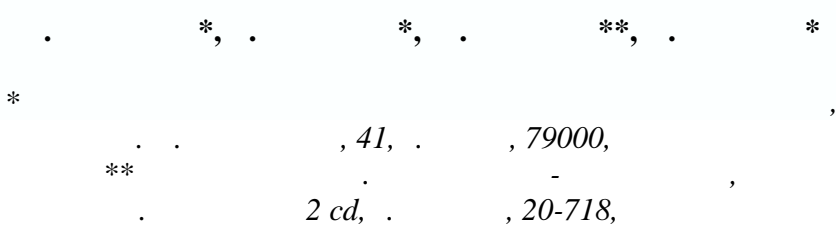

зрез орг новичи р сположен в редк рп тье, з п днее г. мбор, ьвовской обл. н предст вляет ллюви льную и покровную толщу уровня оевой - шестой сверхпойменной терр сы нестр . восточной околице сел р змещен р зрез орг новичи 1, н 3 п дной орг новичи 2. риведены опис ния р зрезов, некоторые результ ты н литических исследов ний отложений, очерчено в жность изучения р зрезов для геоморфологии и п леогеогр фии редк рп тья.

лючевые слов : опорный р зрез, уровень оевой, гляци льный и флюви льний лито- и морфогенез, терр сы.

т ття н дійшл до редколегії 04.04.2009 рийнят до друку 20.09.2009 